\title{
Enchanted: Aino Kallas's Legatonland Memoirs of London between the Wars
}

\author{
PILVI RAJAMÄE
}

\begin{abstract}
The Finnish-Estonian writer Aino Kallas lived in London between 1922 and 1934, being the wife of the first Estonian ambassador to the Court of St James's. In 2011 her memoirs of these years were published in Estonian translation under the title Londoni võlus (Enchanted by London). Being a romantic and a modernist, Kallas in her memoirs combines a heightened sensitivity with the rigours of the modernist style in order to convey in striking images what she recalls about persons and events in London between the wars. The article below will look at some of these characteristic images that convey her vision of London that is full of enchantment.
\end{abstract}

Keywords: Aino Kallas; London; diplomats; royalty; writers; lady explorers between the wars

Aino Kallas, a Finnish-Estonian author well known and highly esteemed on both sides of the Gulf of Finland, was also the wife of the first Estonian ambassador to the Court of St. James's. She lived in London from 1922 to1934. Throughout these years she kept a diary and has later also reminisced about her life there in various collections of essays. In 2011 these reminiscences about her life in the imperial capital were published in Estonian translation (for she wrote in Finnish) under the collective title Londoni võlus (Enchanted by London). This is an interesting book not only because of its content but also the translation and editorial choices, resulting in a mix of periods and attitudes that tell the reader both about the London between the wars, Aino Kallas as a writer and the editorial nostalgia for the times past.

When Kallas arrived in London, she was an established poet and short story writer both in Estonia and Finland. Born in 1878 in Finland, she had married Oskar Kallas in 1900 and they settled first in St. Petersburg and then, in 1903, in Tartu, Estonia. Her new adopted homeland was to provide the material for her mature work, notably her famous prose ballads, some of which were rapidly translated into English when she arrived in London and were published in 1927 under the collective English title Eros the Slayer, with a foreword by John Galsworthy. During the London years she was at the 
peak of her creative powers, a special poignancy and intensity in her work in this period being occasioned by a recent torrid love affair with the famous Finnish poet Eino Leino. This combination of heightened sensibility and the overwhelming impact of the bustle and glitter of London on a receptive mind whose experience of metropolitan living was necessarily rather limited, has lent a special brilliance and charm to her memoirs about her London years.

These memoirs are scattered between various collections, supplemented by the diaries which she kept throughout her life. The book under discussion here is a collection of essays gleaned from four separate collections of reminiscences, mostly published towards the end of her life. These are Kiirtepild (Sunburst) (1929), the only one published during her stay in London; Leiuretkel Londonis. Kaksteist aastat Eesti Londoni-saatkonnas aastail 1922-1934. Mälestusi Inglismaast, Ameerikast ja Hollandist (Exploring London. Twelve Years at the Estonian Embassy in London between 1922 and 1934. Reminiscences about England, America and Holland) (1945); Kanssavaeltaija ja ohikulkijoita. Muistoja ja muotokuvia (Travel Companions and Passers-by. Memoirs and Portraits) (1945) and Uusia kanssavaeltaija ja ohikulkijoita. Muistoja ja muotokuvia (More Travel Companions and Passers-by. Memoirs and Portraits) (1946). Beside the text, what makes this collection interesting is its editing and the selection of illustrative material. These give the book a dimension quite different and separate from the text.

Kallas's fiction in usually tragic and her mood exalted, leading to the classification of her writing in Estonia as neo-romantic. Hers is an interesting combination of intense romanticism and stark modernism. Embracing fully the then fashionable preoccupation with the image, a novel way of rendering reality through intense, epiphanic moments isolated from the flow of mundane reality to arrive at new insights and deeper truths, she makes a determined effort to find these moments and convey her impressions of them in this fragmented, kaleidoscopic manner. She was a strikingly good-looking woman with a touch of a femme fatale, ever mindful of her impact on others. In her memoirs this comes across as a determination to seek out the singular, charismatic, colourful and, if possible, also exotic. This applies both to how she describes her official duties as the Estonian ambassador's wife and the literary and political figures she meets.

Kallas's London is an enchanted place. Because of the circles she moves in as an ambassador's wife the picture is narrow but intense, channelled through her charismatic persona which is constantly on the lookout for colour and magic. Court receptions ad literary dinners are enlivened by exotic characters, ephemeral and insubstantial, and the merely anecdotal is given the profundity 
RAJAMÄE

of cultural generalization. This fairyland is necessarily kaleidoscopic and elegiac, as it is recalled in snippets largely during the grim years of the Second World War.

Legationland, the world of embassies and receptions, by definition dull, circumspect and riddled with intrigue, would seemingly allow little scope for flights of fancy. However, the romance of metropolitan life, the sheer thrill of entering and being part of the high society of the imperial capital of the then biggest empire in the world permeates her memoirs. This is indeed her 'great adventure' (20) on which her family embarks in 1922, leaving provincial Helsinki in a blizzard, not knowing whether their ship would make it to the port of London.

The romance is twofold, for besides voyaging into the unknown (neither she nor her husband were well versed in either the English language or culture, the culture of imperial Russia having been French and German-oriented), they were going to London as pioneers and trailblazers. It was only four years before that Estonia had become an independent state and it was to be their lot to build up the Estonian embassy in London from scratch.

In time, and largely under her tutelage, the tall and cramped but romantic building of the Estonian embassy at 167 Queen's Gate in South Kensington would become a hub of bustling social activity. The new states vied with each other for notice and they had to try double hard to stand out in the crowd. However, this daily slog is lightly passed over in favour of incidents and characters that make up the glittering pageantry of life in diplomatic circles. It is peopled by mysterious figures that emerge from the mists of memory to add a colourful touch or detail to what must have otherwise been a rather dull routine. Thus we find that the Estonian Independence Day celebrations are enlivened by anonymous yet memorable gate-crashers - a loud and bearded giant of a man who claimed to be a missionary but was most probably just after a free glass of champagne or a bevy of old and heavily painted local ladies who had made gate-crashing smaller embassies their personal sport. Then there are the first Baltic ambassadors to the Court of St James's - the Lithuanian Tomas Naruševičius, large, reserved, with the wisdom of a peasant, and the tall and thin Latvian Georgs Bisenieks, deadly pale, his regular Grecian features crowned by a crop of golden locks, and both already marked by death. The most ambitious of the new states was Poland which seemed to have spared no expense to establish itself as a serious player on the international arena. Her second ambassador to London, Konstanty Skirmunt, the tall, silver-haired and sharp-featured aristocrat seems to have impressed Kallas as cold, distant and 
Enchanted: Aino Kallas's Legatonland Memoirs of London between the Wars

alert, more like a Jesuit padre or a French courtier of the ancien regime, with polished manners but sly and calculating.

A group apart were the Nordic embassies. Kallas confesses to a deep affinity with the Norwegian mind-set and lauds the Norwegian ambassador Benjamin Vogt in lavish terms. An incomparable raconteur belied by his ascetic-looking exterior, he seems to have avoided the diplomatic pitfalls of superficiality and excessive smoothness. In a stark contrast with the homeliness of the Norwegians was the cool and pompous reserve of the Swedes who emphatically distanced themselves from the Baltic states. The Finns, understandably the closest to Kallas, are represented by three ambassadors the millionaire industrialist Ossian Donner who had a Scottish wife and no time for Finnish language and culture; the modest, frank and dutiful Armas Herman Saastamoinen, as Finnish as a man can be; and George Gripenberg of an ancient lineage, a man who might have stepped out of the medieval world of tourneys and knights in shining armour.

The absolute highlight of Kallas's stay in London seems to have been the 'courts', royal receptions at Buckingham Palace. These occasions have etched themselves into Kallas's memory with the intensity of an expressionist painting - all is line and colour. A special poignancy is lent to these recollections by the manifold toppling of royal houses during both world wars (she was not to know that most of the sovereigns mentioned below would be reinstated to their honours after the Second World War). As a result, the whole panoply of the royal court and its ceremonies has assumed a fairy tale-like aspect:

A ruler's court as such is one of the rarest forms of life and one of the most special, the more so when both wars have done everything possible to overthrow royal houses. I recently saw a cartoon of rulers who have lost their thrones. There were eight of them: the Kings of Denmark and Norway, the Dutch Queen Wilhelmina, the Emperor of Abyssinia, the Kings of Spain, Portugal and Greece, all of whom have lost their crown during the present world war, at least temporarily. To them must be added the victims of revolutions after the previous world war: the murdered Emperor of All Russias and the Emperor of Germany who died in exile. Kings and emperors have thus become quite rare and they are receding to that world of fairy tale where we first espied them in our early childhood -an ermine-lined purple cloak thrown about their shoulders, a crown on head and sceptre and orb in hand. (All translations mine P. R.) (65) 
RAJAMÄE

While the male ambassadors and ministers attended the King's levée three or four times a year, their wives were presented at the court, together with the debutantes, three or four times in spring. These necessitated the purchase of expensive court dresses with detachable trains which were beyond Kallas's means who solved the problem by ordering them at the less distinguished but ingenious dressmaker's in a side street whose skills rivalled the big houses of Worth or Reville who commanded for one such dress alone a third of the annual salary of the Estonian ambassador. Then there were the long hours of practicing the curtsy with a dancing master. And finally, the car crammed full of embassy personnel to the Palace with nervous shouts of 'Don't wrinkle my train!' and 'Don't stand on my shoes'. (68) What followed was akin to a waking dream:

Imagine six or sometimes eight hundred women - already on the ground floor of the Palace we had become separated from our husbands to meet them only after the court - all except Hindu, Chinese and Siamese women in identical dresses the individuality of which was expressed only through the choice of fabric and colour. There were no prescriptions but black was ruled out and debutantes to be presented at court all wore white. One could see dark red or purple velvet or silk of the same colour, also green in all its shades. The preponderant material however was silver and gold brocade which was the first choice and doubtlessly merged best with its surroundings.

One could not help looking back. The sight was straight from a fairy tale: a vision of an endless row of swans flowing up the stairs and along corridors, their reflections multiplied by the many floor-length mirrors. [...] We walked through brightly lit corridors and state rooms without number and finally through the half-lit Throne Room to the room assigned for the ladies of the diplomatic corps. (69)

When the ladies had been presented to the King and Queen and the visiting heads of state, including the Indian maharajas, came the turn of the men who filed past in the splendour of the court dress. And then the debutantes who curtsied so low they were in danger of toppling over.

Besides these formal occasions Kallas's contacts with the royals remained rare, as the old custom of asking ambassadors and their wives over for the weekend at Windsor once a year was inexplicably dropped shortly before the Estonians' turn arrived. Thus her very few meetings with them have assumed a disproportionate magnitude in the book, formal small talk being assigned significance way beyond the occasion's importance.

Members of the diplomatic corps were expected to pay a visit to different members of the royal family, a number of whom expired before the Estonians' 
turn came. Nevertheless, Kallas could meet Queen Victoria's daughter, the elderly Princess Beatrice, and Princess Mary, Viscountess Lascelles, the daughter of George V. The former had obviously been briefed by aides to ask about Mme Kallas's occupation as a writer but she is bowled over at this interest in her own person. The concert at Princess Mary's residence in Park Lane is almost ruined by the Estonian ambassador's coughing fit during a violin solo.

Occasional glimpses of royalty are afforded by the wedding of the Duke of York (the future George VI) to Lady Elizabeth Bowes-Lyon (1923) where Kallas marvels at the age-defying, porcelain doll-like beauty of the 76-year-old tsarina Maria Feodorovna (Dagmar of Denmark), the mother of the recently murdered tsar Nicholas II, and the delicate flower-like bride herself illuminated by a sudden burst of sunlight in an otherwise gloomy Westminster Abbey as she walks up the isle. (88) The dashing Prince of Wales makes a memorable appearance at the Spanish embassy by picking up and returning to its owner, the dancer Carmencita, one of the unmanageable combs which keep flying about as her performance is electrified by the royal presence. (90) Queen Mary's iron self-control and tireless goodwill receive due recognition as she makes her way to the Royal Lodge at Ascot.

Visiting royals flit past like exotic butterflies. At the state dinner given by the ambassador of Afganistan at the Dorchester Hotel the Estonian ambassador is placed, by a quirk of fate, next to Queen Soraya, an incomparable, ethereal beauty, and has the honour of saving her diamond tiara from crashing to the floor as it disentangles itself from her raven locks. (127) Marie, the Queen of Romania, another famous beauty, makes as double appearance, as the proud blond Aphrodite-like vision in pearl-bedecked aquamarine dress dancing the quadrille with King George $\mathrm{V}$ at a ball in Buckingham Palace and, more mundanely, as an aspiring author at the PEN-Club, pale and drawn in sober black, her desire to break out of the golden cage of royal duty condemned outright by Kallas who prefers her royals to retain their mystique. (171-2)

Another exotic breed to have gripped Kallas's imagination is eccentric women explorers and authors with whom she must have felt a certain affinity. These women had dared to break out of their gilded cages in search of adventure, cut striking figures and brought a whiff of exotic lands with them to fog-bound London. Kallas's encounters with them being necessarily brief, at dinner table or tea parties, she relies on her eye for colour and detail, encapsulating in a few brush strokes and snippets of conversation the perceived personas of these women.

Thus we meet Rosita Forbes, the now largely forgotten but then worldfamous traveller and author at an MP's dinner. She is defined through her laugh 
RAJAMÄE

and clothes, appropriately enough, for she was also famous for her cultivated chic, even under desert conditions:

Rosita Forbes laughed. [...] Slightly over thirty. Stylized into a snake. Wearing a blue-green tulle dress with a long-sleeved silver-sequined metal jacket that glistened like snakeskin. Tall, very slender, not rounded, without hips, without breasts, writhing and snakelike. The skin white as milk, with the cream drained off, slightly bluish. Hair copper this time. Eyes big and rounded, eyebrows plucked into a thin line, nails pink. (106)

Forbes was then at the height of her fame, she having crossed the most inaccessible part of the Libyan desert in search of the legendary Kufara, the most isolated oasis in the Sahara, in the winter of 1920-21. Besides many more travels, she had also trekked by foot and mule through Abyssinia in 1925 and made a film about her exploits, both of which Kallas mentions. At the time Kallas met her, she was also writing romantic fiction about well-to-do but bored heroines, not unlike their creator, adventuring in exotic settings, now considered mediocre.

Another bored self-styled aristocratic explorer Lady Richmond Brown has merited a longer entry, Kallas having had a brief conversation with her which she dutifully renders. By the time Kallas met her at a talk she gave to the National Political League, Brown had also attained the peak of her fame, having published a book of travels Unknown Tribes, Uncharted Seas (1924). A scandalous, if brave, figure, she was a teller of tall tales, much like her companion on these travels F. A. Mitchell-Hedges to whom she was not married. The couple became notorious later when it was shown that the mysterious crystal skull that they claimed to have found in the British Honduras in 1924 was a modern fake (a detail that has incidentally escaped the editor who has provided a gushing footnote about them). F. A. Mitchell-Hedges was an adventurer par excellence who did not unduly care for veracity and facts, being at one point in his career labelled 'the British Baron Munchhausen'. (See references to pertinent internet sources at the back.) He would have long sunk into obscurity, were it not for the controversy surrounding the crystal skull which has earned him a mention in one of the Indiana Jones movies.

Kallas takes her cue for tackling Lady Brown from the beginning of the preface of her book where, with ineffable aristocratic disdain, she claims being 'fed up' (2007: 3). Not to succumb to that dire condition that would surely accompany the rest cure she has been prescribed after a serious operation, she flees to the Caribbean and adventure. What follows is an account of venturing into unexplored wilderness in search of the cucunaque tribe of natives who 
Enchanted: Aino Kallas's Legatonland Memoirs of London between the Wars

supposedly had refused contact with the whites for the last five hundred years but would miraculously succumb to the lure of the adventurous English couple. This lurid and unlikely tale, for neither were the seas uncharted nor the Kuna people of Panama unknown, has a certain breathless and rebellious quality to it. Kallas is completely bowled over:

It is futile trying to render the contents of this book. Every page exudes the joy and freshness of open air living, the lure of danger and facing up to it, the intoxication of discovery and the Unknown, man's struggle with the elements, his losses and victories. (213)

When meeting her in person, after Brown's expedition of digging in the British Honduras in 1925, Kallas cherishes the contrast between the presumed rough explorer wielding guns and spades who has lived "for months on end completely cut off from everything culture can offer" (214) and the refined aristocratic disdain of the high society lady whom she meets:

In the midst of a small circle and a centre of attention was a very elegant lady, seemingly bored by all this attention. She is smoking a cigarette, pulling closer her rich sable coat, as if she were cold, and coughing once in a while. The open coat reveals a black silk dress, cut very short, with a wide lace border. Two rows of pearls.

This woman looks as if she has just come from a beauty parlour, where she has been steamed, shaped, powdered and manicured according to the latest fashion. Her hands command attention: these are aristocratic, beautiful and well-kept and nervous to exhaustion. The refined beauty of her face is more French than Anglo-Saxon: the nose small and crooked, hair raven, eyes bold and proud, a small scar at the corner of the mouth.

At first glance she looks like a trinket, the product of extremely refined culture, as if she were surrounded by an atmosphere of hot baths and the scented boudoir. (215)

Her small talk is trite ("I hate high heels (her heels had very high French heels!) and short dresses - I've been in shorts for months") and sentimental ("Can't bear this atmosphere any longer, I'm longing for the tropics. They have claimed me, bewitched me for ever") and she answers the questions addressed to her with "remarkable condescension and barely disguised boredom" (213-14). Nevertheless, Kallas chooses to conclude her portrait with her remark "I have lived a full life - all moments brimming full of shimmering life!" (Ibid.)

Mrs Alec Tweedie, traveller and author, is defined through her interiors, Kallas having had a chance to visit her in her new apartment in Devonshire 
RAJAMÄE

House, then one of the very few remaining grand London mansions of the aristocracy:

I can't really say what these rooms are: a collection, a museum, a world fair or a bit of the tropics and exotic east in the middle of London. [...] Already the view from the windows is out of the one thousand and one nights: a grey sea of fog, sprinkled with innumerable spots of light. In the daytime one can see the wide green park and its continuation St. James's Park, up to the Houses of Parliament and the Thames. On the other side Buckingham Palace, the royal gardens and Hyde Park, not in the blue-red haze of Paris but in a yellow, smoking mist, the origin and nature of which are equally mysterious.

Mrs Alec Tweedie has presented the greater part of her collection - including things brought home from Finland - to London museums, because of shortage of space alone. But enough remains, her travels and worlds - Chinese silk embroidery and patterned Indian carpets, a tiger skin from Africa, a chandelier from a church in Nuremberg, a big turtle shell from somewhere in the South Seas, red and gold, a lot of red! Cupboards and shelves full of rare and precious china and Chinese ivory figures, a collection of copper utensils, weapons, idols. [...] Mrs Tweedie's grandmother was a collector of lace and her granddaughter has continued the tradition. Everywhere in the rooms are walls covered with most beautiful lace, framed and glass-covered - with the name attached like in a proper museum.

And then pictures of Mrs Tweedie: paintings, drawings, sculpture and cartoons and dozens of her own watercolours from her last five-year world tour when she covered about 100,000 leagues. (216-217)

Of all the female explorers, it is Mrs Tweedie to whom Kallas can relate best, Mrs Tweedie having made her mark as a fledgling travel writer with her account of a journey through Finland. Also her tragedy-strewn life must have rung a responsive chord with Kallas, who speaks movingly about Mrs Tweedie's loss of her great fortune and the perishing of her husband and two sons. She cuts an indomitable figure in a coat of wine-red Chinese silk:

There is enough left of her once resplendent beauty to guess how she may have looked twenty-thirty years ago. She has been a proud, shapely beauty, of more than average height, her carriage as if that of a Byzantine empress, the face an Italianate oval, big blue, heavy-lidded black eyes and black, though lacklustre hair. Only the mouth has a trace of the Anglo-Saxon, hard and narrow. There is in her a special hard, harsh brilliance like in polished, shining metal. (221-222) 
The question whether she has ever been afraid during her travels receives a sharp denial and then, in the midst of all this splendour, the chilling admission: "I don't love life any more. That's why I'm not afraid." (222)

As an aspiring author intent on making her mark also in the Englishspeaking world, it is the literary London that has the greatest fascination for Kallas. She provides a series of engaging snapshots of the authors she met at the PEN-Club dinners, some still remembered, others quite forgotten. The international PEN-Club (founded in 1921) was just seven years old when Kallas became a member and one can sense the excitement of being part of this new international organization designed to bring people together after the havoc and devastation wrought by the First World War.

The pride of place is given to John Galsworthy, the then PEN-Club chairman who wrote the foreword to Kallas's first collection of stories to appear in English translation in 1927. With customary skill, she draws a delicate and respectful portrait:

There are artists whose facial features can be gleaned from their works. Their presence is on every page like an unseen stamp. Galsworthy has such a face. It is always present in his books, like his voice can be heard between the lines.

A thin, clean-shaven face, very English, one would say English above all else. Nothing loud or noisy, not even a whiff of it. The forehead, hair retreating, is high and domed, a little like Gerhart Hauptmann's. The mouth especially vivid, the head twitching nervously, thin lips. The grey eyes, not very large, full of the same mixture of mockery, humanity and compassion, especially the last two. The mockery surely only on the surface, as in his books. His whole being full of beauty, balance and amicable humanity, full of English reserve. Honour which is never boring in its superiority. Always and everywhere fair play - a clean game - as the English would say - this is Galsworthy. (166)

Bernhard Shaw is rendered predictably as a brilliant raconteur, an egocentric of the first order, who outshines his kindly hosts, the Fabian authors Beatrice and Sidney Webb. Herbert George Wells and Gilbert Keith Chesterton appear as bon vivants, interestingly both nervous and shy, despite their great bulk. An exotic touch is provided by Robert Bontine Cunningham-Graham, the son of a Scottish laird and a Spanish mother, who at sprightly seventy still retains the air of a Spanish cavallero with his exploits as a gaucho in the South American pampas to his credit. James Joyce, whose Ulysses (1922) was still prohibited in England and whose fame was the more scandalous because of it, cuts an unsympathetic figure as a guest at a PEN-Club dinner: 
A man cowardly, sly like a wild beast that at any moment might slink back to his subterranean cave. Or a snail that stretches its tentacles carefully. The head strangely narrow and small, almost microcephalic. Eyes deep in their sockets and without eyelashes - or at least it seemed so - red-rimmed and almost dark red. A hanging nose like a Jesuit's, the mouth that of an ascetic, a flagellant, narrow as a line. A little goatee, as if glued to the end of his chin, grey in his hair. Hands small and reluctant, white and feeble, reptilian. A man who does not smile, laugh or speak. (170-71)

Another forbidden author, also on sexual grounds, Radclyffe Hall, the author of the now classic lesbian novel The Well of Loneliness, fares no better:

I had seen this author at the PEN-Club more than once, always accompanied by a divorced woman wearing a monocle - they were inseparable. Radclyffe Hall never wore an evening gown, always a suit of black or yellowish raw silk with a motley shirt front and a man's necktie. She had a fine-boned, chiselled, gaunt, suffering face. Radclyffe Hall was one of those innocent women inclined by tragic fate to homosexuality who from early childhood are erotically drawn to their own sex. In The Well of Loneliness she depicts her sufferings which have taken her from one disappointment and humiliation to another. This is an honest, unadorned book, well-written, though instinctively repulsive to any normally sexual person. (138)

Kallas is especially drawn to frail romantic natures, be they the Japanese author living in London Komai Gonnosuke, a frequenter of the PEN-Club in his kimono and sandals whose small lyrical songs sound like "frail, falling cherry petals" (170) or the Celtic poets Ernest and Grace Rhys, mystical and otherworldly. Sheila Kaye-Smith, a miniature porcelain doll-like woman, delicate and girlish, whose vigorous table talk belies her appearance. The now forgotten, ethereal Madeline Mason-Manheim might be a visitor from the Moon or a fairy, so out of this world are her poems.

Kallas's memoirs of London, richly illustrated as they are, have the potential of a coffee table book, yet the glitter of the prose is marred by careless editing and unintentional humorous effects that result from it. The book has a distinct pre-Second World War feel. This is partly due to translation. The editor, Mall Jõgi, has personally translated a number of pieces and it is remarkable how neatly her translations merge in style and language with the overwhelming majority made in the 1940s by Johannes Aavik, an esteemed Estonian linguist then working in exile. This is romanticism of the highest order. Both Kallas and Aavik through his translation come across as the hallowed representatives of that vanished interwar world, forever encapsulated in that magical cocoon 
of period language, both pretentious, self-conscious, showy, mindful of what impression they make.

Likewise, the photographs chosen to illustrate the text look distinctly prewar, are of uneven quality and sometimes questionable in their selection. The principle of selection is not given, so one can presume that the family photos, views of London and maybe all of the pictures in the book come from Kallas's own collection. Be that as it may, the placement of some of these pictures in the text is hilarious at best and baffling in some cases. Despite the plethora of images available of the royal family, famous actors and actresses, authors and authoresses Kallas mentions in her book in the National Portrait Gallery alone, faceless, blurred, out-of-focus images mar the book or images are conspicuous by their absence. Then there is unintended humour when a vignette about visiting a soap factory on the western coast, not named, is illustrated with a photo of Mahatma Gandhi of all people (not mentioned by Kallas anywhere in the book) visiting a textile mill in Lancashire in the north of England. Even more incomprehensible is the picture of the boyish Jawaharlal Nehru, the would-be first prime minister of independent India, taken in 1905 in his pristine and very English Harrow school uniform, and never mentioned in the book, accompanying the episode describing an Indian fakir performing on Brompton Road. The most perplexing of all is the photograph of Kallas's diplomatic visa to Finland in 1920 illustrating a story of a mysterious, closed and shuttered house quite close to the Estonian embassy at the door of which Kallas happened to witness the return of its owner - a deranged widow of a British official whose husband and children had been murdered in her presence while stationed abroad. A similar mystery surrounds the choice of a picture of the warehouses on the Thames to illustrate Kallas's account of the English love of spiritualism and her trip to Musselburgh Castle in Northern England which was supposed to be haunted.

To the modern reader the book is firmly of its period. Its self-consciously modernist style, convoluted syntax, preciosity of language, starkness of images, all combine to render more poignant the world it describes, the world more charming and engaging because it is no more.

\author{
Pilvi Rajamäe \\ pilvi.rajamae@ut.ee \\ Tartu Ülikool \\ Maailma keelte ja kultuuride kolledž \\ Lossi 3 \\ 51003 Tartu \\ EESTI / ESTONIA
}


RAJAMÄE

\section{References}

Kallas, A. 2011. Londoni võlus. Tallinn: Tammerraamat.

F. A. Michell-Hedges: Credibility Problems. - http:/www.strangemag.com/crystalskull/ crystalcredibilitty.htm (accessed July 9, 2011).

Richmond Brown, L. M. A. 2007. Unknown Tribes, Uncharted Seas. Waterville Maine: Thorndike Press.

Smith, D. J. D. 2010. Appointments in the Sun (Rosita Forbes). http://www.slideshare. net/eleuthera/rosita-forbes-biography (accessed 11 July, 2011).

Walsh, J. M. 2010. Skull of Doom? - http:/www.faqsorg/periodicals/201002/ 1984818921-html (published February 1, 2010, accessed 9 July, 2011). 